\title{
Changes in glutamate receptors in dyskinetic parkinsonian monkeys after unilateral subthalamotomy
}

\author{
Vincent A. Jourdain, PhD, ${ }^{1,2}$ Nicolas Morin, BPharm, PhD,, Laurent Grégoire, BSc, ${ }^{1}$ \\ Marc Morissette, $\mathrm{PhD},{ }^{1}$ and Thérèse Di Paolo, $\mathrm{PhD}^{1,2}$ \\ ${ }^{1}$ Neuroscience Research Unit, Centre Hospitalier Universitaire de Québec; and ${ }^{2}$ Faculty of Pharmacy, Laval University, \\ Quebec, Canada
}

OBJECT Unilateral subthalamotomy is a surgical procedure that may be used to alleviate disabling levodopa-induced dyskinesias (LIDs) in patients with Parkinson disease (PD). However, the mechanisms involved in LID remain largely unknown. The subthalamic nucleus (STN) is the sole glutamatergic nucleus within the basal ganglia, and its lesion may produce changes in glutamate receptors in various areas of the basal ganglia. The authors aimed to investigate the biochemical changes in glutamate receptors in striatal and pallidal regions of the basal ganglia after lesion of the STN in parkinsonian macaque monkeys.

METHODS The authors treated 12 female ovariectomized monkeys with 1-methyl-4-phenyl-1,2,3,6-tetrahydropyridine (MPTP) to induce PD-like symptoms, treated 8 of these animals with 3,4-dihydroxy-L-phenylalanine (L-DOPA; levodopa) to induce LID, and performed unilateral subthalamotomy in 4 of these 8 monkeys. Four additional monkeys were treated with saline only and were used as controls. The MPTP monkeys had previously been shown to respond behaviorally to lower doses of levodopa after the STN lesion. Autoradiography of slices from postmortem brain tissues was used to visualize changes in the specific binding of striatal and pallidal ionotropic glutamate receptors (that is, of the $\alpha$-amino-3-hydroxy 5-methyl-4-isoxazole propionate [AMPA] and N-methyl-D-aspartate [NMDA] NR1/NR2B subunit receptors) and of metabotropic glutamate ( $\mathrm{mGlu}$ ) receptors (that is, $\mathrm{mGlu} 2 / 3$ and $\mathrm{mGlu} 5$ receptors). The specific binding and distribution of glutamate receptors in the basal ganglia of the levodopa-treated, STN-lesioned MPTP monkeys were compared with those in the saline-treated control monkeys and in the saline-treated and levodopa-treated MPTP monkeys.

RESULTS The autoradiographic results indicated that none of the pharmacological and surgical treatments produced changes in the specific binding of AMPA receptors in the basal ganglia. Levodopa treatment increased the specific binding of NMDA receptors in the basal ganglia. Subthalamotomy reversed these increases in the striatum, but in the globus pallidus (GP), the subthalamotomy reversed these increases only contralaterally. Levodopa treatment reversed MPTPinduced increases in mGlu2/3 receptors only in the GP. mGlu2/3 receptor-specific binding in the striatum and GP decreased bilaterally in the levodopa-treated, STN-lesioned MPTP monkeys compared with the other 3 groups. Compared with mGlu5 receptor-specific binding in the control monkeys, that of the levodopa-treated MPTP monkeys increased in the dorsal putamen and remained unchanged in the caudate nucleus and in the GP.

CONCLUSIONS These results implicate glutamate receptors in the previously observed benefits of unilateral subthalamotomy to improve motor control.

http://thejns.org/doi/abs/10.3171/2014.10.JNS141570

KEY WORDS subthalamotomy; levodopa-induced dyskinesia; MPTP monkey; Parkinson disease; levodopa; glutamate receptor; functional neurosurgery

\footnotetext{
ABBREVIATIONS AMPA = $\alpha$-amino-3-hydroxy-5-methyl-4-isoxazolepropionic acid; $\mathrm{GP}=$ globus pallidus; $\mathrm{GPe}=\mathrm{GP}$ externus; $\mathrm{GPi}=\mathrm{GP}$ internus; $\mathrm{LID}=$ levodopa-induced dyskinesia; $\mathrm{mGlu}=$ metabotropic glutamate; MPTP = 1-methyl-4-phenyl-1,2,3,6-tetrahydropyridine; NMDA = N-methyl-D-aspartate; PD = Parkinson disease; STN = subthalamic nucleus; 6-OHDA = 6-hydroxydopamine.

SUBMITTED July 4, 2014. ACCEPTED October 16, 2014

INCLUDE WHEN CITING Published online May 1, 2015; DOI: 10.3171/2014.10.JNS141570.

DISCLOSURE Dr. Jourdain received a studentship from the Fonds d'Enseignement et de Recherche of the Faculté de Pharmacie of Université Laval and from the Centre de recherche en endocrinologie moléculaire et oncologique et en génomique humaine and currently holds a postdoctoral scholarship from the Fonds de la recherche en santé du Québec. Dr. Morin held a professional health care studentship from the Fonds de la recherche en santé du Québec.
} 
$\mathrm{T}$ HERE is strong evidence that glutamatergic neurotransmission is altered in Parkinson disease (PD) and also during the development and expression of levodopa-induced dyskinesias (LIDs)..$^{10,50}$ Reducing glutamate overactivity by blocking the ionotropic receptors for $N$-methyl-D-aspartate (NMDA) and for $\alpha$-amino3-hydroxy-5-methyl-4-isoxazolepropionic acid (AMPA) effectively reduces LID in parkinsonian primates. ${ }^{34,58,85}$ However, similar results in humans have not been conclusive. ${ }^{39,53}$

Besides via the aforementioned 2 ionotropic glutamate receptors, the actions of glutamate are also mediated via $\mathrm{G}$ protein-coupled metabotropic glutamate $(\mathrm{mGlu})$ receptors. Among the 8 known mGlu receptors, the mGlu2/3 and mGlu 5 receptors have attracted much interest because of their distribution within the basal ganglia. ${ }^{75}$ Activation of mGlu2/3 receptors inhibits glutamate release in the striatum and in other basal ganglia nuclei involved in LID. ${ }^{18}$ Their specific role in motor control remains unclear because both mGlu $2 / 3$ receptor agonists and antagonists produce anti-parkinsonian-like effects in rodent models of PD. ${ }^{33,52}$ However, no clinical trials have investigated the use of drugs targeting the $\mathrm{mGlu} 2 / 3$ receptors to treat $\mathrm{PD}$ or LID. The use of negative allosteric modulators of the mGlu5 receptor has been reported for the treatment of LID in animal models ${ }^{22,28,44,45,66}$ and also in PD patients. ${ }^{6,80}$

The primate basal ganglia receives massive glutamate afferents from several cortical areas, ${ }^{36,37}$ from the centromedian/parafascicular thalamic nuclei, ${ }^{68,77}$ and from the subthalamic nucleus (STN). ${ }^{14}$ The STN is currently the surgical target of choice in patients whose symptoms are refractory to medication or who have disabling LID. In fact, almost $60 \%$ of neurosurgeons still perform some kind of lesioning, and subthalamotomies are offered to the patient as often as other surgical lesions. ${ }^{31}$ Subthalamotomies are often used to treat patients who cannot afford deep brain stimulation. ${ }^{26}$ Moreover, transcranial MRguided focused ultrasound is a new technique for lesioning deep brain structures and has been recently introduced for thalamotomy, ${ }^{20}$ which may revive the interest in lesioning for treating movement disorders.

We recently demonstrated that unilateral subthalamotomy in MPTP-treated monkeys with LID had beneficial effects bilaterally on the parkinsonian scores both in monkeys receiving saline (baseline) or various doses of 3,4-dihydroxy-L-phenylalanine (L-DOPA; levodopa). ${ }^{29}$ Postmortem analysis showed only postsynaptic modifications in the dopaminergic system. We observed a reversal of the levodopa-induced decreases in $\mathrm{D}_{1}$ receptor-specific binding ipsilateral to the subthalamotomy and no effects on the $\mathrm{D}_{2}$-related system. ${ }^{30}$ A reduction of STN glutamatergic activity had beneficial effects on PD symptoms, as predicted by the direct and indirect pathways model of the basal ganglia. ${ }^{19}$ Given the glutamatergic nature of the STN, subthalamotomy is hypothesized to induce changes in levels of glutamate receptors in the basal ganglia through direct STN projections ${ }^{60}$ or through a normalization of cortico- and thalamostriatal pathways. In the present study, ionotropic (AMPA and NMDA) receptors and metabotropic (mGlu2/3 and mGlu5) receptors, which are known to be modulated in PD and LID, were investigated using receptor-binding autoradiography in levodopa-treated, STN-lesioned MPTP monkeys with LID and compared with those in saline-treated controls and in salinetreated or levodopa-treated MPTP monkeys.

\section{Methods}

\section{Animals and Experimental Treatments}

The number of animals used in this study was kept to the minimum required for statistically valid analyses. Experiments were carried out with 16 female ovariectomized macaque monkeys (Macaca fascicularis) (weight range $3.4-5.4 \mathrm{~kg}$ ) in agreement with the standards of the Canadian Council on Animal Care. The Laval University committee for protection of animals approved this study. Four saline-treated monkeys served as controls, and 12 monkeys were treated with systemic MPTP and developed a severe parkinsonian syndrome. Four of these MPTP-treated monkeys were treated with saline (salinetreated, MPTP monkeys). The other 8 MPTP-treated monkeys were chronically treated with levodopa/benserazide and developed LID. Four of these 8 monkeys did not receive subsequent treatments (levodopa-treated, MPTP monkeys), while the remaining 4 underwent unilateral subthalamotomy (levodopa-treated, STN-lesioned MPTP monkeys) by stereotactic injection of ibotenic acid into the subthalamus. A unilateral rather than a bilateral subthalamotomy was used to allow a comparison between the lesioned and nonlesioned sides in the same animal, which reduced interindividual variability. Moreover, bilateral lesioning may induce behavioral deficits, enhance LIDs, or even induce hemiballism.

All MPTP-treated monkeys in the present study displayed similar baseline parkinsonism scores (saline-treated MPTP monkeys $10.1 \pm 1.1$, levodopa-treated MPTP monkeys $9.7 \pm 0.8$, and levodopa-treated, STN-lesioned MPTP monkeys $11.1 \pm 0.7$ ) assessed according to the Laval University Disability Scale for MPTP monkeys. ${ }^{25}$ The detailed behavioral assessment and pharmacological/ surgical treatments of these monkeys have been previously reported..$^{29,45}$ Histopathology of the lesioned versus nonlesioned STN was included in the behavioral study, by visualizing the lesion with cytochrome oxidase and cresyl violet. Moreover, a rostrocaudal reconstruction of the lesion was also demonstrated. ${ }^{29}$

\section{Tissue Preparation}

At the end of the experiments, all monkeys were killed with pentobarbital. All 12 MPTP monkeys were killed 24 hours after their last levodopa/benserazide or saline treatment. The animals' brains were flash-frozen in isopentane $\left(-45^{\circ} \mathrm{C}\right)$. Brains were cut into $12-\mu \mathrm{m}$-thick coronal sections on a cryostat $\left(-18^{\circ} \mathrm{C}\right)$ at levels corresponding approximately to A18-A22, according to the atlas of Szabo and Cowan. ${ }^{81}$ Sections were mounted onto Super Frost Plus (Fisher) slides and stored at $-80^{\circ} \mathrm{C}$ until use in assays. All measurements were made at the postcommissural levels.

\section{AMPA Receptor Autoradiography}

Tissue sections for AMPA receptor-binding assays were preincubated for 20 minutes in a $50 \mathrm{mM}$ Tris- $\mathrm{HCl}$ 
buffer, $\mathrm{pH} 7.4$, followed by incubation for 60 minutes at $4^{\circ} \mathrm{C}$ in the same buffer supplemented with $5 \mathrm{nM}\left[{ }^{3} \mathrm{H}\right]-$ Ro 48-8587 (1.92 × $10^{12} \mathrm{~Bq} / \mathrm{mmol}$; Novartis). Nonspecific binding was determined in a set of adjacent tissue slides via incubation with $50 \mu \mathrm{M}$ of the AMPA antagonist 1,4-dihydro-6-(1H-imidazol-1-yl)-7-nitro-2,3-quinoxalinedione hydrochloride (YM 90K, Tocris). After the incubations, the labeled sections were washed 2 times for 30 seconds in ice-cold buffer, followed by brief dipping in bidistilled water $\left(4^{\circ} \mathrm{C}\right) .^{57}$ Lastly, the slide-mounted tissue sections were dried overnight at room temperature and incubated with $\left[{ }^{3} \mathrm{H}\right]$-sensitive films (BIOMAX MR Film, Kodak) for 4 weeks along with standards ( ${ }^{3} \mathrm{H}$-microscales, GE Healthcare).

\section{NMDA NR1/NR2B Receptor Autoradiography}

Tissue sections for NMDA (containing NR1/NR2B subunits, thereafter called NMDA NR1/NR2B) receptorbinding assays were preincubated twice for 10 minutes at room temperature in a buffer of $50 \mathrm{mM}$ Tris- $\mathrm{HCl}$ and $10 \mathrm{mM}$ EDTA, pH 7.4. Sections were then incubated for 90 minutes at room temperature in the same buffer containing $5 \mathrm{nM}\left[{ }^{3} \mathrm{H}\right]$-Ro $25-6981\left(0.95 \times 10^{12} \mathrm{~Bq} / \mathrm{mmol} ; \mathrm{F}\right.$. Hoffman-La Roche). Nonspecific binding was determined with $10 \mu \mathrm{M}$ of the NMDA antagonist Ro 04-5595 (F. Hoffmann-La Roche). After two 5-minute washes and one 15 -minute wash at $4^{\circ} \mathrm{C}$ in the Tris-EDTA buffer, sections were rinsed for 10 seconds in ice-cold distilled water. ${ }^{54}$ The slide-mounted tissue sections were dried and incubated with $\left[{ }^{3} \mathrm{H}\right]$-sensitive films as described above.

\section{mGlu2/3 Receptor Autoradiography}

Tissue sections for $\mathrm{mGlu} 2 / 3$ receptor-binding assays were preincubated for 30 minutes at $4^{\circ} \mathrm{C}$ in a phosphate

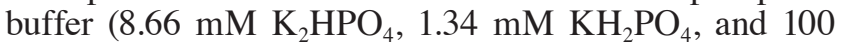
$\mathrm{mM} \mathrm{KBr}$ ), $\mathrm{pH}$ 7.6. Sections were then incubated for 90 minutes at room temperature in the same buffer containing $5 \mathrm{nM}\left[{ }^{3} \mathrm{H}\right]-\mathrm{LY} 341495\left(1.48 \times 10^{12} \mathrm{~Bq} / \mathrm{mmol}\right.$; American Radiolabeled Chemicals). Nonspecific binding was determined in the presence of $20 \mathrm{mM}$ glutamate. After two 30 -second washes at $4^{\circ} \mathrm{C}$ in the phosphate buffer, sections were rinsed for 30 seconds in ice-cold distilled water. ${ }^{71}$ The slide-mounted tissue sections were dried and incubated with $\left[{ }^{3} \mathrm{H}\right]$-sensitive films as described above.

\section{mGlu5 Receptor Autoradiography}

Tissue sections for mGlu5 receptor-binding assays were preincubated for 30 minutes at room temperature in a Krebs-Ringer HEPES buffer (20 mM HEPES, $118 \mathrm{mM}$ $\mathrm{NaCl}, 4.8 \mathrm{mM} \mathrm{KCl}, 2.5 \mathrm{mM} \mathrm{CaCl}_{2}, 1.2 \mathrm{mM} \mathrm{MgSO}_{4}$, and $10 \mathrm{mM} \mathrm{NaOH}$ ), $\mathrm{pH}$ 7.4. Sections were then incubated for 15 minutes at room temperature in this buffer, containing $5 \mathrm{nM}\left[{ }^{3} \mathrm{H}\right]$-ABP688 $\left(3.02 \times 10^{12} \mathrm{~Bq} / \mathrm{mmol}\right.$; Novartis $)$ with $0.05 \mathrm{mg} / \mathrm{ml}$ bovine serum albumin. Nonspecific binding was determined in the presence of $10 \mu \mathrm{M} 2$-methyl6-(phenylethynyl)-pyridine (Tocris). After three 20-minute washes at $4^{\circ} \mathrm{C}$ in the Krebs-Ringer HEPES buffer, sections were rinsed for 5 seconds in ice-cold distilled water. ${ }^{56}$ The slide-mounted tissue sections were dried and incubated with $\left[{ }^{3} \mathrm{H}\right]$-sensitive films as described above.

\section{Data Analysis}

For each brain region examined, we performed autoradiographic analyses on 3-6 brain slices from each ani$\mathrm{mal}$. The intensity of the radiolabeling was quantified with computerized densitometry (NIH ImageJ 64-bit mode, v.1.46) analysis of autoradiographs placed on a constant illumination light table and photographed with a video camera (XC-77, Sony) connected to a Power Macintosh G4 computer. Signals on the autoradiographs were measured as optical density in the caudate nucleus, the putamen, and the pallidal complex and corrected for nonspecific binding in each experiment. Subsequently, optical gray densities were transformed into Bq per milligram of tissue equivalent using a standard curve generated with $\left[{ }^{3} \mathrm{H}\right]$-standards ( ${ }^{3} \mathrm{H}$-microscales, GE Healthcare). Results were then converted into femtomoles per milligram of tissue using specific activity of the radioligands.

Data in figures show the means and SEM. Statistical comparisons of data were performed by a 2-way ANOVA (brain subdivisions and pharmacological or surgical treatment) mixed model using paired and nonpaired values with "animal" considered a random effect, followed by post hoc pairwise comparisons with least squares means tests. Analyses were conducted using SAS software (version 9.3, SAS Institute, Inc.). A p value of $\leq 0.05$ was considered statistically significant.

\section{Results \\ Effect of MPTP Denervation and Treatments on Glutamate Receptors}

Figure 1 shows a schematic of the subdivisions of the caudate nucleus and putamen and representative autoradiographs of AMPA, NMDA NR1/NR2B, mGlu2/3, and mGlu5 receptor binding in the postcommissural striatum of the levodopa-treated MPTP monkeys that underwent a unilateral subthalamotomy to alleviate their LID. For all 4 glutamate receptors investigated, autoradiographic labeling was high in the caudate nucleus and putamen, whereas it was much lower in both compartments of the globus pallidus (GP), namely, in the internal and external regions (that is, the GP internus [GPi] and GP externus [GPe], respectively). The changes in receptor-specific binding and distribution in response to the 3 experimental treatments are summarized in Table 1.

\section{AMPA Receptor Binding}

The MPTP treatment nonsignificantly increased specific binding of $\left[{ }^{3} \mathrm{H}\right]-\mathrm{Ro} 48-8587$ to the AMPA receptor in both the caudate nucleus and the putamen (Fig. 2). Administration of levodopa to the MPTP monkeys tended to decrease AMPA receptor-specific binding, but this decrease did not reach statistical significance. The subthalamotomy also produced no significant change in AMPA receptor binding. No specific binding of $\left[{ }^{3} \mathrm{H}\right]-\mathrm{Ro} 48-8587$ to AMPA receptors was detected in the 2 GP regions in all of the experimental groups examined (data not shown).

\section{NMDA NR1/NR2B Receptor Binding}

Specific binding of [ $\left.{ }^{3} \mathrm{H}\right]-\mathrm{Ro} 25-6981$ to NMDA NR1/ NR2B receptors was unaffected by MPTP in all subdivi- 


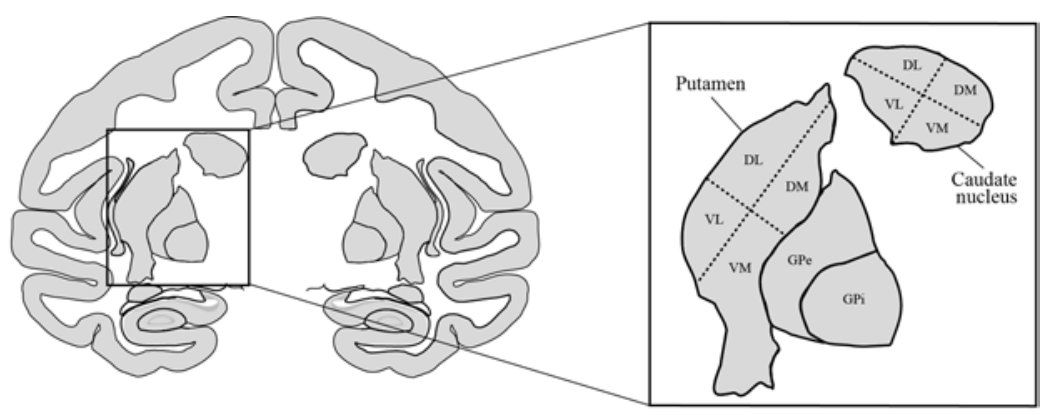

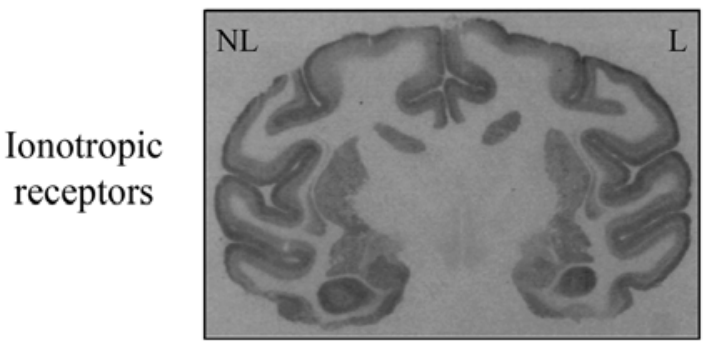

AMPA

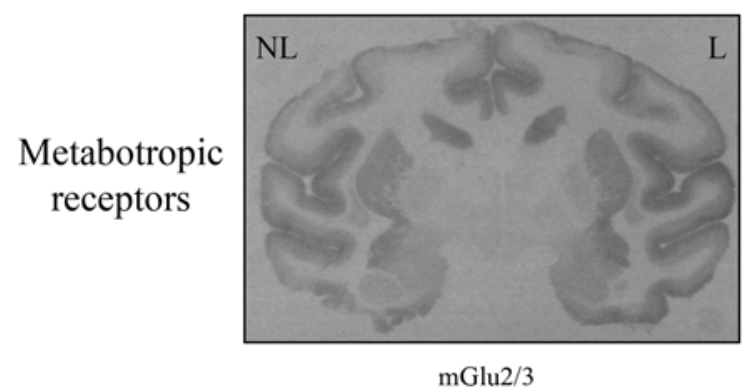

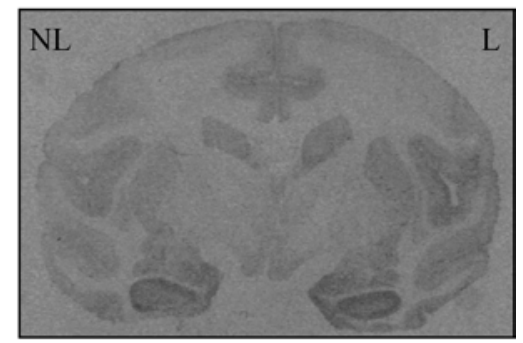

NMDA NR1/NR2B

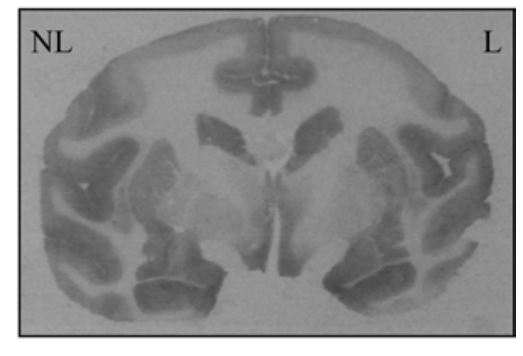

mGlu5

FIG. 1. Representative autoradiographs of coronal brain sections showing AMPA, NMDA NR1/NR2B, mGlu2/3, and mGlu5 receptor binding in the posterior striatum of the levodopa-treated MPTP monkeys that received a unilateral subthalamotomy to alleviate their LID; the autoradiographs are compared with the schematic of the monkey brain (adapted with permission from Martin R.F., Bowden D.M. [2000]. Primate Brain Maps. Elsevier Science. () 2000 University of Washington) shown at the top. The dorsolateral (DL), dorsomedial (DM), ventrolateral (VL), and ventromedial (VM) subregions of the caudate nucleus and putamen, as well as the GPe and GPi, are shown. L = ipsilateral to STN lesion; NL = contralateral to STN lesion.

sions of the caudate nucleus and the putamen (Fig. 3A and B). Levodopa treatment significantly increased NMDA NR1/NR2B receptor-specific binding in both striatal regions. Lesion of the STN reversed these levodopa-induced increases bilaterally to control values in both the caudate nucleus and the putamen. No striatal difference was observed between the lesioned versus the nonlesioned side of the STN.

The MPTP treatment did not affect the binding of $\left[{ }^{3} \mathrm{H}\right]-$ Ro 25-6981 to the NMDA NR1/NR2B receptors in the GP (Fig. 3C). Levodopa treatment significantly increased the NMDA NR1/NR2B receptor binding in the GPe and showed a trend toward an increase in the GPi. These levodopa-induced increases were reversed contralaterally to the STN lesion, whereas the NMDA NR1/NR2B binding remained increased ipsilaterally.

\section{mGlu2/3 Receptor Binding}

Striatal $\left[{ }^{3} \mathrm{H}\right]-\mathrm{LY} 341495$ binding to the mGlu2/3 receptor increased in the medial parts of the caudate nucleus and ventromedial putamen of saline-treated MPTP monkeys and remained unchanged in the lateral subregions of the striatum (Fig. 4A and B). Striatal mGlu2/3 receptor-specific binding in the levodopa-treated MPTP monkeys was similar to that in controls. In the ventral caudate nucleus and all subdivisions of the putamen, the subthalamotomy led to a bilateral decrease in mGlu2/3 receptor-specific binding compared with that in the control and in saline- or levodopa-treated MPTP monkeys. The subthalamotomy decreased mGlu2/3 receptor binding less in the dorsal than in the ventral caudate nucleus. The mGlu $2 / 3$ receptor binding was higher in the dorsomedial caudate nucleus ipsilateral to the STN lesion than in its contralateral counterpart (Fig. 4A).

Both compartments of the pallidal complex showed a mGlu $2 / 3$ receptor binding pattern similar to that in the striatum (Fig. 4C). The MPTP treatment increased mGlu2/3 receptor binding, which was reversed by the levodopa treatment. The STN lesioning and MPTP treatment extensively decreased pallidal mGlu $2 / 3$ receptor binding by $>$ 
TABLE 1. Summary of the functional changes in glutamate receptors in the motor (dorsal) putamen and in the GP after treatments with MPTP, levodopa (L-DOPA), or unilateral subthalamotomy*

\begin{tabular}{|c|c|c|c|}
\hline \multirow[b]{2}{*}{ Receptor } & \multicolumn{3}{|c|}{ Treatment } \\
\hline & MPTP† & L-DOPA & Subthalamotomy§ \\
\hline AMPA & $\begin{array}{l}\text { No change in putamen \& no detect- } \\
\text { able binding in GP }\end{array}$ & $\begin{array}{l}\text { No change in putamen \& no de- } \\
\text { tectable binding in GP }\end{array}$ & $\begin{array}{l}\text { No change in putamen \& no detectable binding in } \\
\text { GP }\end{array}$ \\
\hline $\begin{array}{l}\text { NMDA (contain- } \\
\text { ing NR1/NR2B } \\
\text { subunits) }\end{array}$ & No change in putamen or GP & Increased in putamen \& GP & $\begin{array}{l}\text { Reversed the L-DOPA-induced increases in puta- } \\
\text { men; in GP, no change ipsilat \& reversed the } \\
\text { L-DOPA-induced increases contralat }\end{array}$ \\
\hline mGlu5 & No change in putamen or GP & $\begin{array}{l}\text { Increased in putamen \& no signifi- } \\
\text { cant change in GP }\end{array}$ & Remained increased in putamen \& no change in GP \\
\hline
\end{tabular}

\footnotetext{
* All animals whose results are shown in this table were treated with MPTP; a subgroup of these animals was also treated with levodopa, and 4 of the MPTP- and levodopa-treated animals underwent subthalamotomy.

$\dagger$ Changes in receptor binding reported in this column are from comparisons with receptor binding in the control monkeys.

$\ddagger$ Changes in receptor binding reported in this column are from comparisons with receptor binding in the control and saline-treated MPTP monkeys.

$\S$ Changes in receptor binding reported in this column are from comparisons with receptor binding in the levodopa-treated MPTP monkeys.
}

$58 \%$ relative to that in control monkeys, by $>76 \%$ relative to that in saline-treated MPTP monkeys, and by $>65 \%$ relative to that in levodopa-treated MPTP monkeys.

\section{mGlu5 Receptor Binding}

In the caudate nucleus (Fig. 5A), $\left[{ }^{3} \mathrm{H}\right]-\mathrm{ABP} 688$ binding to the mGlu5 receptor was similar in all treatment groups; however, we noted a trend toward an increase in binding among MPTP monkeys treated with levodopa with or without subthalamotomy. In the putamen (Fig. 5B), mGlu5 receptor-specific binding in saline-treated MPTP monkeys was similar to that in the control monkeys, but was higher in the levodopa-treated and STN-lesioned MPTP monkeys than in the controls in all striatal subdivisions except for the ventromedial putamen. Compared with mGlu5 receptor binding in the saline-treated MPTP monkeys, the binding in the lateral putamen was greater in the levodopa-treated MPTP monkeys. However, the mGlu5 receptor binding remained increased in the levodopa-treated, STN-lesioned MPTP monkeys in the dorsolateral and dorsomedial putamen contralateral and ipsilateral to the subthalamotomy, respectively. No change was observed in the ventromedial putamen across all experimental groups.

mGlu5 receptor binding in the GP was unaffected by any of the treatments (Fig. 5C).

\section{Discussion}

Glutamate neurotransmission accounts for approximately $70 \%$ of the synaptic transmission in the central nervous system, making glutamate the most abundant excitatory neurotransmitter. ${ }^{62}$ The STN is the only excitatory structure intrinsic to the basal ganglia, and its lesion is hypothesized to induce changes in the binding activity of glutamate receptors. Therefore, we investigated the changes in glutamate receptors known to be involved in LID in monkeys after MPTP and levodopa treatments and after unilateral subthalamotomy. Lesion of the STN increases striatal glutamate levels in normal rats $^{83}$ and decreases 6-hydroxydopamine (6-OHDA)-induced elevation of glutamate. ${ }^{16,83}$ Moreover, STN ablation in normal primates decreases pallidal 2-deoxyglucose uptake ${ }^{43}$ and expression of the gene for glutamic acid decarboxylase $67,2^{24}$ together, these observations indicate decreased cellular activity in STN efferent structures.

\section{AMPA Receptor Binding}

AMPA receptors are postsynaptic, glutamate-gated ion channel receptors involved in many brain functions, including neurological disorders. ${ }^{2}$ Some studies in monkeys have reported few or no changes in AMPA receptors in the striatum after MPTP or levodopa treatment, $, 7,72$ while others have noted striatal increases in these receptors in dyskinetic monkeys. ${ }^{12,46}$ A previous autoradiographic study has indicated that AMPA receptor-specific binding was higher in the lateral putamen of PD patients with motor complications (both wearing-off and dyskinesias) than in those without motor complications..$^{13}$ We observed no changes in AMPA-specific binding after the pharmacological and surgical treatments. One study has also reported that surgical ablation of the STN resulted in no change in AMPA receptor levels in the basal ganglia, ${ }^{11}$ while another observed an 11\% increase in AMPA receptors in the substantia nigra pars reticulata. ${ }^{63} \mathrm{~A}$ recent electrophysiological study has shown that the effects of highfrequency stimulation of the STN, known to exert positive effects on parkinsonian symptoms, were not mediated via AMPA receptors. ${ }^{38}$ Rather than changes in AMPA receptor density, altered trafficking of its subunits between the vesicular and postsynaptic membranes may be associated with overactive AMPA receptor activity in PD and LID. ${ }^{73}$ For example, an increase in the Glu2/3 subunit in the postsynaptic fraction of AMPA receptors may render striatal neurons more sensitive to glutamate. ${ }^{73}$ The above evidence suggests that AMPA receptors participate in the expression of LID, probably through membrane or vesicular sub- 

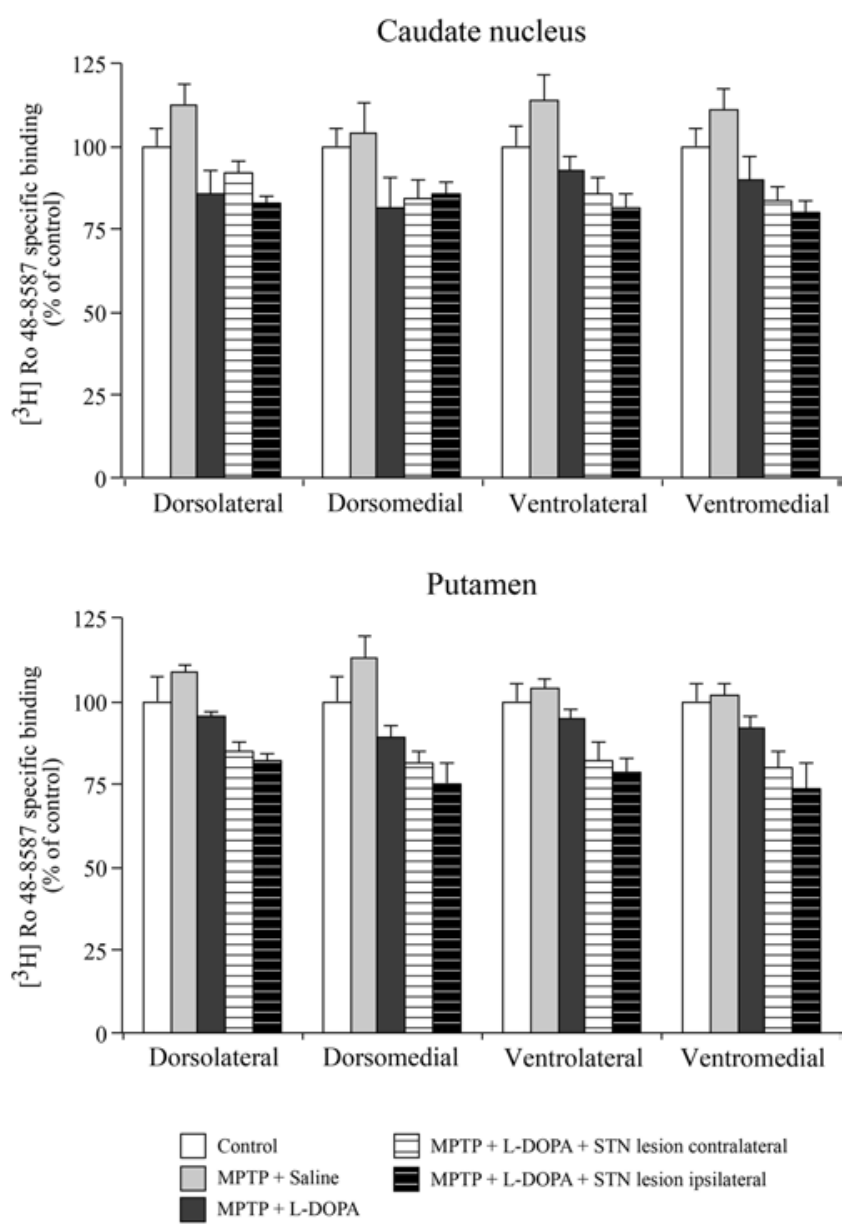

FIG. 2. AMPA receptor-specific binding in the caudate nucleus $\left(\mathrm{F}_{12,45}=\right.$ $0.89, p=0.545)$ (upper) and putamen $\left(F_{12.45}=1.68, p=0.130\right)$ (lower) of saline-treated control monkeys; saline-treated MPTP monkeys; levodopa-treated MPTP monkeys; and levodopa-treated, STN-lesioned MPTP monkeys. L-DOPA = levodopa.

unit trafficking, but not in the clinical effects of lesioning or stimulating interventions for PD treatment.

\section{NMDA NR1/NR2B Receptor Binding}

The NMDA receptor is the other major ionotropic postsynaptic glutamate receptor in the brain. Administration of the NMDA noncompetitive antagonist amantadine to MPTP-treated monkeys ${ }^{7,8,21}$ or to PD patients ${ }^{42,84}$ has been shown to reduce LID. It has been proposed that the NR2B subunit is involved in the development of LID because its binding sites increase both in dyskinetic patients and in MPTP-treated monkeys. . $^{27,46,54}$ Moreover, the activated, phosphorylated form of NR2B plays a more important role in dyskinesia than the nonphosphorylated NR2B. ${ }^{64,65}$ However, the application of NR2B-selective antagonists has yielded conflicting results. The compound CP-101,606 decreased peak-dose LID in a small cohort of PD patients, ${ }^{51}$ but increased LID in MPTP-treated marmosets; 49 in addition, CP-101,606 showed antiparkinsonian activity in monkeys, ${ }^{79}$ but not in PD patients. ${ }^{51}$ While pharmacologi-
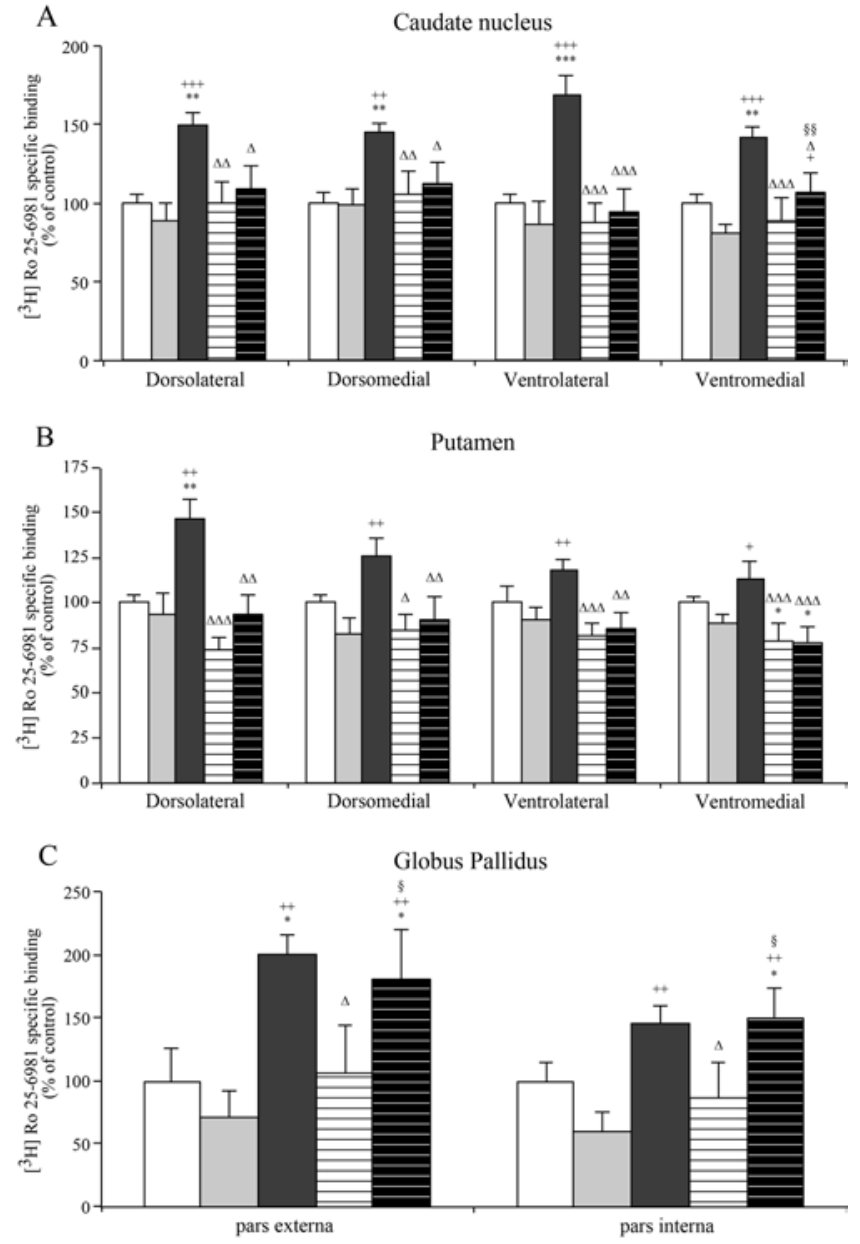

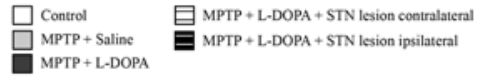

FIG. 3. NMDA NR1/NR2B receptor-specific binding in the caudate nucleus $\left(F_{12,45}=2.69 ; p<0.05\right)(A)$, putamen $\left(F_{12.45}=2.10 ; p=0.05\right)$ (B), and GP $\left(\right.$ GPi F $_{4,15}=6.23, p<0.01$ and $\left.\mathrm{GPe} \mathrm{F}_{4,15}=5.26, p<0.05\right)$ (C) of saline-treated control monkeys; saline-treated MPTP monkeys; levodopa-treated MPTP monkeys; and levodopa-treated, STN-lesioned MPTP monkeys. Various symbols indicate the following levels of statistical significance and comparisons: ${ }^{*} p<0.05,{ }^{* *} p<0.01$ versus controls; $+p<0.05,++p<0.01,+++p<0.001$ versus MPTP treatment; $\Delta p<0.05$, $\Delta \Delta p<0.01$, and $\Delta \Delta \Delta p<0.001$ versus levodopa treatment; and $\S p<$ 0.05 and $\S \S p<0.01$ versus contralateral to STN lesion.

cal blockage of NR2B with some agents (for example, CI1041 and Co 101244) has antidyskinetic activity in primate models of PD,, 25 other compounds (Ro 25-6981 and Ro 63-1908) failed to reproduce such activity in 6-OHDAtreated rats. ${ }^{67}$

In the present study, the NMDA NR1/NR2B-specific binding was unaffected by MPTP. By contrast, increases of NMDA NR1/NR2B-specific binding in the striatum were observed in the levodopa-treated MPTP monkeys, consistent with previous findings in dyskinetic primates and PD patients with motor complications..$^{13,27,46,54}$ In the levodopa-treated, STN-lesioned MPTP monkeys, bilateral levels of NMDA NR1/NR2B returned to normal values, 
A
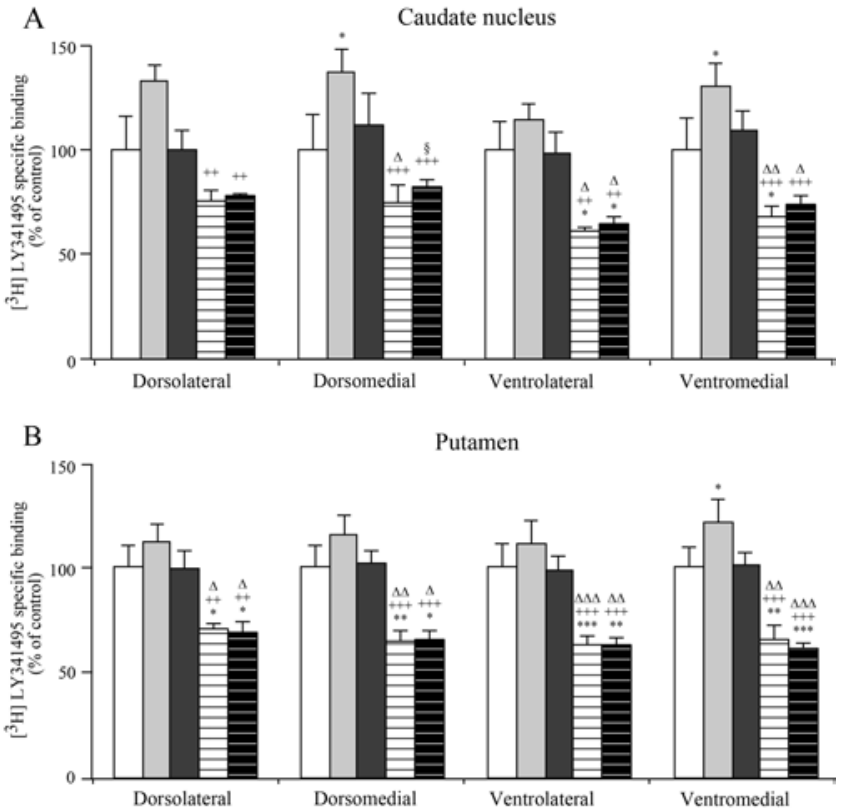

$\mathrm{C}$

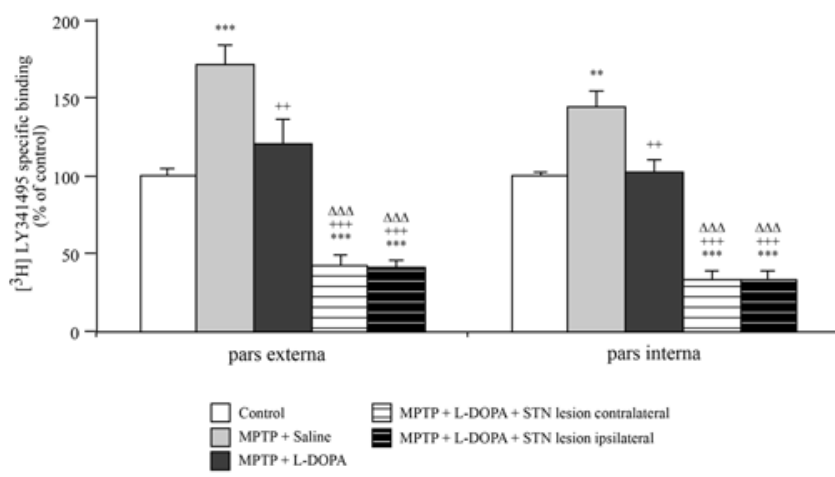

FIG. 4. mGlu2/3 receptor-specific binding in the caudate nucleus $\left(F_{12,45}\right.$ $=3.08, p<0.01)(A)$, putamen $\left(F_{1245}=5.37, p<0.001\right)(B)$, and $G P(G P i$ $F_{4,15}=43.37, p<0.001$ and $\left.G P e F_{4,15}=29.55, p<0.001\right)(C)$ of salinetreated control monkeys; saline-treated MPTP monkeys; levodopatreated MPTP monkeys; and levodopa-treated, STN-lesioned MPTP monkeys. Various symbols indicate the following levels of statistical significance and comparisons: ${ }^{*} p<0.05,{ }^{* *} p<0.01$, and ${ }^{* * *} p<0.001$ versus controls; $++p<0.01$, and $+++p<0.001$ versus saline-treated MPTP monkeys; and $\Delta p<0.05, \Delta \Delta p<0.01$, and $\Delta \Delta \Delta p<0.001$ versus levodopa treatment.

suggesting an effect of the subthalamotomy, most probably from a modulation of the corticostriatal overactive pathway in LID. These results are consistent with those from a study in rats showing that L-DOPA significantly increased both the phosphorylated and nonphosphorylated forms of the NMDA NR1/NR2B receptors. ${ }^{65}$ In the same study, high-frequency stimulation of the STN increased only the nonphosphorylated form of NMDA NR1/NR2B. However, the study did not report results of combining both treatments, that is, of L-DOPA treatment with subthalamic stimulation. Because the setting in that study differed from ours (for example, in the animal models used and in the combined pharmacological or surgical treatments), we cannot easily draw conclusions from our observation
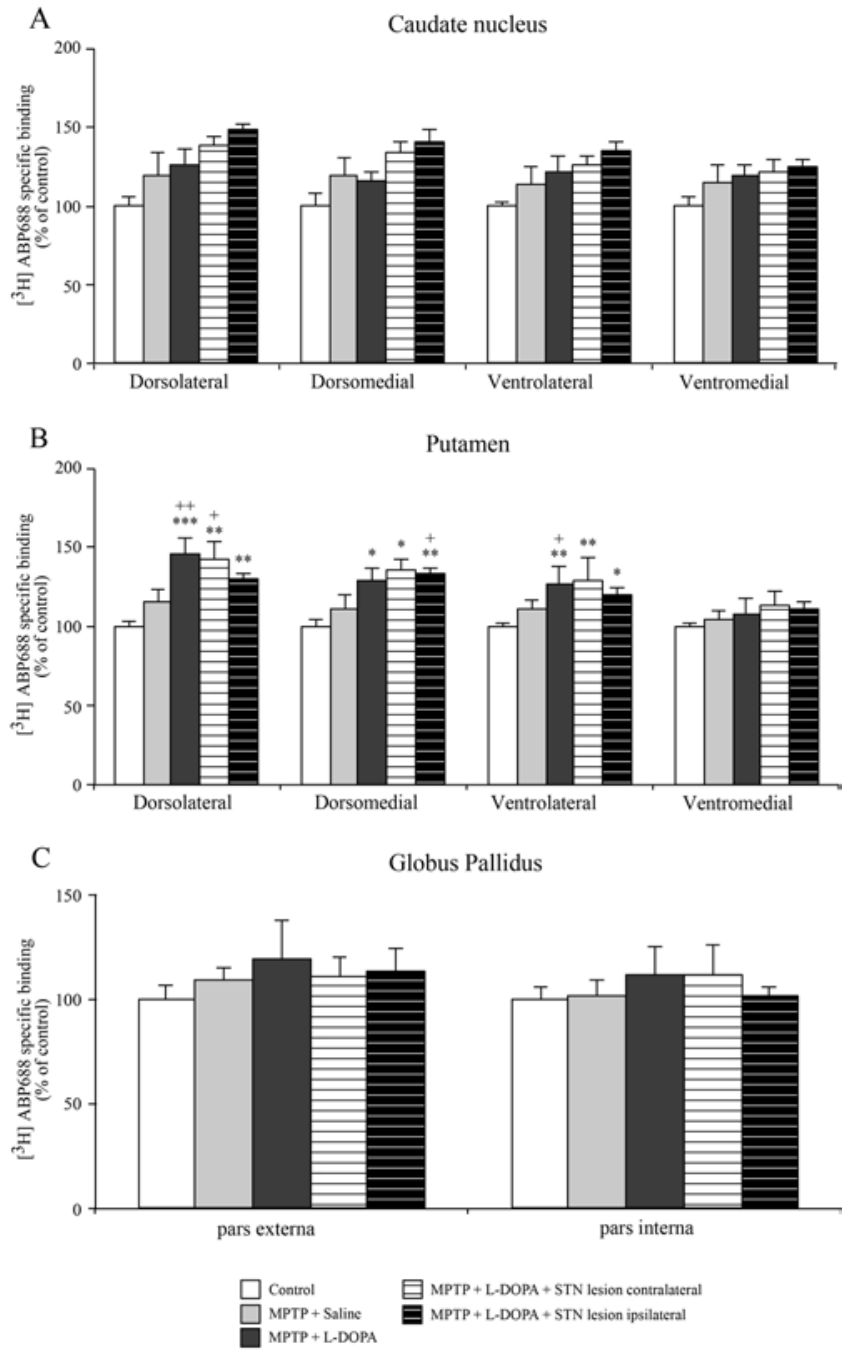

FIG. 5. mGlu5 receptor-specific binding in the caudate nucleus $\left(F_{1245}=\right.$ $1.51, p=0.180)(A)$, putamen $\left(F_{12,45}=3.37, p<0.01\right)(B)$, and $G P(G P i$ $F_{4.15}=0.41, p=0.751$ and $G P e F_{4,15}=0.49, p=0.695$ ) (C) of saline-treated control monkeys; saline-treated MPTP monkeys; levodopa-treated MPTP monkeys; and levodopa-treated, STN-lesioned MPTP monkeys. Various symbols indicate the following levels of statistical significance and comparisons: ${ }^{*} p<0.05,{ }^{* *} p<0.01$, and ${ }^{* * *} p<0.001$ versus controls; $+p<0.05$ and $++p<0.01$ versus saline-treated MPTP monkeys.

that alteration of the STN induced changes in the NMDA NR1/NR2B receptor binding.

In all experimental groups, the GP segments displayed a pattern of NMDA NR1/NR2B-specific binding similar to that in the striatum, except for the levodopa-treated, STN-lesioned MPTP monkeys in which the NMDA NR1/ NR2B-specific binding remained elevated in the GP region ipsilateral to the subthalamotomy. The decrease in binding contralateral to the lesion may be explained by a compensatory mechanism from a decreased glutamatergic input from the STN. The STN neurons in primates also project to the contralateral GP via the dorsal supraoptic decussation. ${ }^{15}$ The strength of this efferent connection is currently unknown but may contribute to the results observed here. More studies are warranted to assess this 
observed discrepancy in outcomes between ipsi- and contralateral subthalamotomy. The NMDA receptor density decreases in the GP (equivalent to the GPi in primates) and in the substantia nigra pars reticulata ipsilateral to the STN lesion in normal rats. ${ }^{11,63}$ Our results add evidence to previous studies demonstrating the involvement of the NMDA receptors in LID.

\section{mGlu2/3 Receptor Binding}

The specific role of the $m$ Glu2/3 receptors in the basal ganglia remains to be elucidated. They closely interact with the dopamine system, pre- and postsynaptically in the dopamine circuitry. ${ }^{1,5,35,47}$ Administration of mGlu2/3 receptors agonists after exposure to 6-OHDA in rats or before MPTP injection in mice have yielded interesting neuroprotective effects, ${ }^{4,17,48}$ and blockade of the mGlu2/3 receptors amplifies the MPTP insult. ${ }^{4}$

Autoradiographic studies in monkeys reported that MPTP treatment resulted in no changes in the mGlu2/3 receptor-specific binding in the striatum. ${ }^{46,69}$ Similarly, we observed that MPTP treatment did not change mGlu2/3 receptor-specific binding in the putamen and in the lateral caudate nucleus but increased that in the medial caudate nucleus. Levodopa treatment causes either a decrease in striatal mGlu2/3 receptors ${ }^{46}$ or no change in parkinsonian monkeys ${ }^{69}$ or PD patients. ${ }^{71}$ Consistent with previous results, we found that the striatal and pallidal levels of $\mathrm{mGlu} 2 / 3$ receptors were at normal levels in the saline- or levodopa-treated MPTP monkeys. However, mGlu2/3 receptors were strongly decreased in the levodopa-treated, STN-lesioned monkeys compared with levels of these receptors in the controls and in the saline- or levodopatreated MPTP monkeys.

Group II metabotropic receptors (mGlu2/3) are located presynaptically on corticostriatal neurons and on subthalamonigral terminals. ${ }^{61}$ Their expression in both the GPe and the GPi suggests localization on subthalamopallidal neurons, but this has not been demonstrated yet. If they are indeed localized to subthalamopallidal neurons, a subthalamotomy would reduce $\mathrm{mGlu} 2 / 3$ receptors in both the GPi and GPe because both regions receive afferent glutamatergic neurons from the STN. ${ }^{76}$ The same observation could also apply to the reduction in the striatum, since the STN also projects to the striatum. ${ }^{32,76}$ This scenario does not exclude a reduction of the $\mathrm{mGlu} 2 / 3$ receptors on the corticostriatal efferents, which may express the $\mathrm{mGlu} 2 / 3$ receptors presynaptically. ${ }^{82}$ To our knowledge, no other reports have examined the effects of surgical alleviation of LID on the expression of $\mathrm{mGlu} 2 / 3$ receptors; therefore, more studies are warranted to fully address the mechanisms implicated in the effect of lesions of the STN.

\section{mGlu5 Receptor Binding}

mGlu5 receptors are mainly located postsynaptically on striatal projection neurons and interneurons ${ }^{23}$ and are expressed on few cortico- and thalamostriatal presynaptic terminals. ${ }^{59}$ Their wide distribution in the basal ganglia has generated interest to use them as a potential therapeutic target for treating PD and LID. ${ }^{78}$ Lesion of the nigrostriatal pathway via MPTP treatment has been reported to increase mGlu5 receptor-specific binding, measured by autoradiography, in the striatum, ${ }^{45,56,70}$ whereas other studies $^{55}$ and also the present one showed no significant increase in mGlu5 receptors in the striatum.

The most striking change in mGlu5 receptors is observed in MPTP-treated monkeys after chronic levodopa treatment. Motor complications induced by levodopa correlated with an increase of mGlu5 receptors in the posterior striatum. ${ }^{45,55,56,70}$ Consistent with these previous reports, striatal levels of the mGlu 5 receptors were increased or tended to be increased in all MPTP-treated monkeys treated with levodopa, including those that underwent subthalamotomy.

One report studied the effects of systemic administration of an mGlu5 receptor antagonist and of subthalamic lesion on dyskinesia in 6-OHDA-treated rats. ${ }^{40}$ The authors concluded that the negative allosteric mGlu5 modulator 2-methyl-6-(phenylethynyl)-pyridine reduces LID better than subthalamotomy does and that this reduction is correlated with a greater decrease in the number of cells immunoreactive to the LID-associated marker deltaFosB/ FosB. ${ }^{40}$ Currently, no studies combining both deep brain stimulation and mGlu5 receptor manipulation are available, and evidence from subthalamotomy is too insufficient to draw solid conclusions about whether STN alteration may change mGlu5 receptor density. More studies are needed to fully assess the interactions between surgical procedures and the mGlu5 receptor, especially because mGlu5 receptors are located postsynaptically in the $\mathrm{STN}^{3}$ and perisynaptically in the $\mathrm{GPi},{ }^{74}$ structures that are both the main targets in PD surgery. ${ }^{31}$

\section{Conclusions}

AMPA-specific binding remained unchanged by the pharmacological and surgical treatments. The MPTP treatment increased the levels of $\mathrm{mGlu} 2 / 3$ receptors in the nonmotor striatum (that is, in the medial caudate nucleus and ventromedial putamen), as well as in both compartments of the GP. However, it had no effect on all of the other investigated glutamate receptors. Levodopa treatment in MPTP-treated monkeys increased the levels of NMDA NR1/NR2B receptors in the GP and striatum, and also of the mGlu5 receptors in the putamen. The levodopainduced increases in striatal NMDA NR1/NR2B receptors were reversed by subthalamotomy. In the GP, this reversal was contralateral to the STN lesion. The mGlu5 receptors in the basal ganglia were unaffected by the subthalamotomy and remained increased in the striatum. mGlu2/3 receptors displayed an opposite pattern: their density in levodopa-treated MPTP monkeys was similar to that in the controls and decreased in the striatum and in the GP of levodopa-treated, STN-lesioned MPTP monkeys. Considering the presynaptic location of the $\mathrm{mGlu} 2 / 3$ receptors, their decrease in the GP and in the striatum may be the result of the subthalamic lesion and of a reduction in the corticostriatal and/or subthalamostriatal efferent connections, respectively. This decrease may contribute to the alleviation of parkinsonian symptoms and LID after subthalamotomy.

\section{Acknowledgment}

We thank Novartis and Hoffman-La Roche, Switzerland, for providing radioligands. 


\section{References}

1. Adewale AS, Platt DM, Spealman RD: Pharmacological stimulation of group II metabotropic glutamate receptors reduces cocaine self-administration and cocaine-induced reinstatement of drug seeking in squirrel monkeys. J Pharmacol Exp Ther 318:922-931, 2006

2. Ashby MC, Daw MI, Isaac JTR: AMPA receptors, in Gereau RW, Swanson GT (eds): The Glutamate Receptors. Totowa, NJ: Humana Press, 2008, pp 1-44

3. Awad H, Hubert GW, Smith Y, Levey AI, Conn PJ: Activation of metabotropic glutamate receptor 5 has direct excitatory effects and potentiates NMDA receptor currents in neurons of the subthalamic nucleus. J Neurosci 20:7871-7879, 2000

4. Battaglia G, Busceti CL, Pontarelli F, Biagioni F, Fornai F, Paparelli A, et al: Protective role of group-II metabotropic glutamate receptors against nigro-striatal degeneration induced by 1-methyl-4-phenyl-1,2,3,6-tetrahydropyridine in mice. Neuropharmacology 45:155-166, 2003

5. Bauzo RM, Kimmel HL, Howell LL: Interactions between the mGluR2/3 agonist, LY379268, and cocaine on in vivo neurochemistry and behavior in squirrel monkeys. Pharmacol Biochem Behav 94:204-210, 2009

6. Berg D, Godau J, Trenkwalder C, Eggert K, Csoti I, Storch A, et al: AFQ056 treatment of levodopa-induced dyskinesias: results of 2 randomized controlled trials. Mov Disord 26:1243-1250, 2011

7. Bibbiani F, Oh JD, Kielaite A, Collins MA, Smith C, Chase TN: Combined blockade of AMPA and NMDA glutamate receptors reduces levodopa-induced motor complications in animal models of PD. Exp Neurol 196:422-429, 2005

8. Blanchet PJ, Konitsiotis S, Chase TN: Amantadine reduces levodopa-induced dyskinesias in parkinsonian monkeys. Mov Disord 13:798-802, 1998

9. Blanchet PJ, Konitsiotis S, Whittemore ER, Zhou ZL, Woodward RM, Chase TN: Differing effects of N-methyl-D-aspartate receptor subtype selective antagonists on dyskinesias in levodopa-treated 1-methyl-4-phenyl-tetrahydropyridine monkeys. J Pharmacol Exp Ther 290:1034-1040, 1999

10. Blandini F, Armentero MT: New pharmacological avenues for the treatment of L-DOPA-induced dyskinesias in Parkinson's disease: targeting glutamate and adenosine receptors. Expert Opin Investig Drugs 21:153-168, 2012

11. Blandini F, Porter RH, Greenamyre JT: Autoradiographic study of mitochondrial complex I and glutamate receptors in the basal ganglia of rats after unilateral subthalamic lesion. Neurosci Lett 186:99-102, 1995

12. Calon F, Morissette M, Ghribi O, Goulet M, Grondin R, Blanchet PJ, et al: Alteration of glutamate receptors in the striatum of dyskinetic 1-methyl-4-phenyl-1,2,3,6-tetrahydropyridine-treated monkeys following dopamine agonist treatment. Prog Neuropsychopharmacol Biol Psychiatry 26:127-138, 2002

13. Calon F, Rajput AH, Hornykiewicz O, Bédard PJ, Di Paolo T: Levodopa-induced motor complications are associated with alterations of glutamate receptors in Parkinson's disease. Neurobiol Dis 14:404-416, 2003

14. Carpenter MB, Carleton SC, Keller JT, Conte P: Connections of the subthalamic nucleus in the monkey. Brain Res 224:1-29, 1981

15. Carpenter MB, Strominger NL: Efferent fibers of the subthalamic nucleus in the monkey. A comparison of the efferent projections of the subthalamic nucleus, substantia nigra and globus pallidus. Am J Anat 121:41-72, 1967

16. Centonze D, Gubellini P, Rossi S, Picconi B, Pisani A, Bernardi G, et al: Subthalamic nucleus lesion reverses motor abnormalities and striatal glutamatergic overactivity in experimental parkinsonism. Neuroscience 133:831-840, 2005

17. Chan H, Paur H, Vernon AC, Zabarsky V, Datla KP, Crouch- er MJ, et al: Neuroprotection and functional recovery associated with decreased microglial activation following selective activation of mGluR2/3 receptors in a rodent model of Parkinson's disease. Parkinsons Dis 2010:190450, 2010

18. Conn PJ, Battaglia G, Marino MJ, Nicoletti F: Metabotropic glutamate receptors in the basal ganglia motor circuit. Nat Rev Neurosci 6:787-798, 2005

19. DeLong MR: Primate models of movement disorders of basal ganglia origin. Trends Neurosci 13:281-285, 1990

20. Elias WJ, Huss D, Voss T, Loomba J, Khaled M, Zadicario E, et al: A pilot study of focused ultrasound thalamotomy for essential tremor. N Engl J Med 369:640-648, 2013

21. Grégoire L, Jourdain VA, Townsend M, Roach A, Di Paolo T: Safinamide reduces dyskinesias and prolongs L-DOPA antiparkinsonian effect in parkinsonian monkeys. Parkinsonism Relat Disord 19:508-514, 2013

22. Grégoire L, Morin N, Ouattara B, Gasparini F, Bilbe G, Johns D, et al: The acute antiparkinsonian and antidyskinetic effect of AFQ056, a novel metabotropic glutamate receptor type 5 antagonist, in L-Dopa-treated parkinsonian monkeys. Parkinsonism Relat Disord 17:270-276, 2011

23. Gubellini P, Pisani A, Centonze D, Bernardi G, Calabresi P: Metabotropic glutamate receptors and striatal synaptic plasticity: implications for neurological diseases. Prog Neurobiol 74:271-300, 2004

24. Guridi J, Herrero MT, Luquin MR, Guillén J, Ruberg M, Laguna J, et al: Subthalamotomy in parkinsonian monkeys. Behavioural and biochemical analysis. Brain 119:1717-1727, 1996

25. Hadj Tahar A, Grégoire L, Darré A, Bélanger N, Meltzer L, Bédard PJ: Effect of a selective glutamate antagonist on Ldopa-induced dyskinesias in drug-naive parkinsonian monkeys. Neurobiol Dis 15:171-176, 2004

26. Hooper AK, Okun MS, Foote KD, Fernandez HH, Jacobson $\mathrm{C}$, Zeilman P, et al: Clinical cases where lesion therapy was chosen over deep brain stimulation. Stereotact Funct Neurosurg 86:147-152, 2008

27. Hurley MJ, Jackson MJ, Smith LA, Rose S, Jenner P: Immunoautoradiographic analysis of NMDA receptor subunits and associated postsynaptic density proteins in the brain of dyskinetic MPTP-treated common marmosets. Eur J Neurosci 21:3240-3250, 2005

28. Johnston TH, Fox SH, McIldowie MJ, Piggott MJ, Brotchie JM: Reduction of L-DOPA-induced dyskinesia by the selective metabotropic glutamate receptor 5 antagonist 3-[(2-methyl-1,3-thiazol-4-yl)ethynyl]pyridine in the 1-methyl-4-phenyl1,2,3,6-tetrahydropyridine-lesioned macaque model of Parkinson's disease. J Pharmacol Exp Ther 333:865-873, 2010

29. Jourdain VA, Grégoire L, Morissette M, Morin N, Parent M, Di Paolo T: Potentiation of response to low doses of levodopa in MPTP-injected monkeys by chemical unilateral subthalamotomy. J Neurosurg 118:180-191, 2013

30. Jourdain VA, Morin N, Morissette M, Grégoire L, Di Paolo T: Subthalamotomy-induced changes in dopamine receptors in parkinsonian monkeys. Exp Neurol 261:816-825, 2014

31. Jourdain VA, Schechtmann G: Health economics and surgical treatment for Parkinson's disease in a world perspective: results from an international survey. Stereotact Funct Neurosurg 92:71-79, 2014

32. Kita H, Kitai ST: Efferent projections of the subthalamic nucleus in the rat: light and electron microscopic analysis with the PHA-L method. J Comp Neurol 260:435-452, 1987

33. Konieczny J, Ossowska K, Wolfarth S, Pilc A: LY354740, a group II metabotropic glutamate receptor agonist with potential antiparkinsonian properties in rats. Naunyn Schmiedebergs Arch Pharmacol 358:500-502, 1998

34. Konitsiotis S, Blanchet PJ, Verhagen L, Lamers E, Chase TN: AMPA receptor blockade improves levodopa-induced dyskinesia in MPTP monkeys. Neurology 54:1589-1595, 2000 
35. Kronthaler UO, Schmidt WJ: Activation of striatal group II metabotropic glutamate receptors has a differential effect on dopamine-D1 and -D2 receptor antagonist-induced hypokinesia in the rat. Naunyn Schmiedebergs Arch Pharmacol 361:289-297, 2000

36. Künzle H: Bilateral projections from precentral motor cortex to the putamen and other parts of the basal ganglia. An autoradiographic study in Macaca fascicularis. Brain Res 88:195-209, 1975

37. Künzle H: Projections from the primary somatosensory cortex to basal ganglia and thalamus in the monkey. Exp Brain Res 30:481-492, 1977

38. Ledonne A, Mango D, Bernardi G, Berretta N, Mercuri NB: A continuous high frequency stimulation of the subthalamic nucleus determines a suppression of excitatory synaptic transmission in nigral dopaminergic neurons recorded in vitro. Exp Neurol 233:292-302, 2012

39. Lees A, Fahn S, Eggert KM, Jankovic J, Lang A, Micheli F, et al: Perampanel, an AMPA antagonist, found to have no benefit in reducing "off" time in Parkinson's disease. Mov Disord 27:284-288, 2012

40. Levandis G, Bazzini E, Armentero M-T, Nappi G, Blandini F: Systemic administration of an mGluR5 antagonist, but not unilateral subthalamic lesion, counteracts 1-DOPA-induced dyskinesias in a rodent model of Parkinson's disease. Neurobiol Dis 29:161-168, 2008

41. Martin RF, Bowden DM: Primate Brain Maps: Structure of the Macaque Brain. Amsterdam: Elsevier, 2000

42. Metman LV, Del Dotto P, LePoole K, Konitsiotis S, Fang J, Chase TN: Amantadine for levodopa-induced dyskinesias: a 1-year follow-up study. Arch Neurol 56:1383-1386, 1999

43. Mitchell IJ, Sambrook MA, Crossman AR: Subcortical changes in the regional uptake of [3H]-2-deoxyglucose in the brain of the monkey during experimental choreiform dyskinesia elicited by injection of a gamma-aminobutyric acid antagonist into the subthalamic nucleus. Brain 108:405-422, 1985

44. Morin N, Grégoire L, Gomez-Mancilla B, Gasparini F, Di Paolo T: Effect of the metabotropic glutamate receptor type 5 antagonists MPEP and MTEP in parkinsonian monkeys. Neuropharmacology 58:981-986, 2010

45. Morin N, Grégoire L, Morissette M, Desrayaud S, GomezMancilla B, Gasparini F, et al: MPEP, an mGlu5 receptor antagonist, reduces the development of L-DOPA-induced motor complications in de novo parkinsonian monkeys: biochemical correlates. Neuropharmacology 66:355-364, 2013

46. Morin N, Morissette M, Grégoire L, Gomez-Mancilla B, Gasparini F, Di Paolo T: Chronic treatment with MPEP, an mGlu5 receptor antagonist, normalizes basal ganglia glutamate neurotransmission in L-DOPA-treated parkinsonian monkeys. Neuropharmacology 73:216-231, 2013

47. Morishima Y, Miyakawa T, Furuyashiki T, Tanaka Y, Mizuma H, Nakanishi S: Enhanced cocaine responsiveness and impaired motor coordination in metabotropic glutamate receptor subtype 2 knockout mice. Proc Natl Acad Sci U S A 102:4170-4175, 2005

48. Murray TK, Messenger MJ, Ward MA, Woodhouse S, Osborne DJ, Duty S, et al: Evaluation of the mGluR2/3 agonist LY379268 in rodent models of Parkinson's disease. Pharmacol Biochem Behav 73:455-466, 2002

49. Nash JE, Ravenscroft P, McGuire S, Crossman AR, Menniti FS, Brotchie JM: The NR2B-selective NMDA receptor antagonist CP-101,606 exacerbates L-DOPA-induced dyskinesia and provides mild potentiation of anti-parkinsonian effects of L-DOPA in the MPTP-lesioned marmoset model of Parkinson's disease. Exp Neurol 188:471-479, 2004

50. Nevalainen N, Lundblad M, Gerhardt GA, Strömberg I: Striatal glutamate release in L-DOPA-induced dyskinetic animals. PLoS ONE 8:e55706, 2013
51. Nutt JG, Gunzler SA, Kirchhoff T, Hogarth P, Weaver JL, Krams M, et al: Effects of a NR2B selective NMDA glutamate antagonist, CP-101,606, on dyskinesia and Parkinsonism. Mov Disord 23:1860-1866, 2008

52. O’Neill MF, Heron-Maxwell C, Conway MW, Monn JA, Ornstein P: Group II metabotropic glutamate receptor antagonists LY341495 and LY366457 increase locomotor activity in mice. Neuropharmacology 45:565-574, 2003

53. Olanow CW, Stern MB, Sethi K: The scientific and clinical basis for the treatment of Parkinson disease (2009). Neurology 72 (21 Suppl 4):S1-S136, 2009

54. Ouattara B, Belkhir S, Morissette M, Dridi M, Samadi P, Grégoire L, et al: Implication of NMDA receptors in the antidyskinetic activity of cabergoline, CI-1041, and Ro 61-8048 in MPTP monkeys with levodopa-induced dyskinesias. J Mol Neurosci 38: 128-142, 2009

55. Ouattara B, Gasparini F, Morissette M, Grégoire L, Samadi P, Gomez-Mancilla B, et al: Effect of L-Dopa on metabotropic glutamate receptor 5 in the brain of parkinsonian monkeys. J Neurochem 113:715-724, 2010

56. Ouattara B, Grégoire L, Morissette M, Gasparini F, Vranesic I, Bilbe G, et al: Metabotropic glutamate receptor type 5 in levodopa-induced motor complications. Neurobiol Aging 32:1286-1295, 2011

57. Ouattara B, Hoyer D, Grégoire L, Morissette M, Gasparini F, Gomez-Mancilla B, et al: Changes of AMPA receptors in MPTP monkeys with levodopa-induced dyskinesias. Neuroscience 167:1160-1167, 2010

58. Papa SM, Chase TN: Levodopa-induced dyskinesias improved by a glutamate antagonist in Parkinsonian monkeys. Ann Neurol 39:574-578, 1996

59. Paquet M, Smith Y: Group I metabotropic glutamate receptors in the monkey striatum: subsynaptic association with glutamatergic and dopaminergic afferents. J Neurosci 23:7659-7669, 2003

60. Parent A, Hazrati LN: Functional anatomy of the basal ganglia. II. The place of subthalamic nucleus and external pallidum in basal ganglia circuitry. Brain Res Brain Res Rev 20:128-154, 1995

61. Phillips T, Rees S, Augood S, Waldvogel H, Faull R, Svendsen C, et al: Localization of metabotropic glutamate receptor type 2 in the human brain. Neuroscience 95:1139-1156, 2000

62. Platt SR: The role of glutamate in central nervous system health and disease-a review. Vet J 173:278-286, 2007

63. Price RH Jr, Hollingsworth Z, Young AB, Penney JB Jr: Excitatory amino acid receptor regulation after subthalamic nucleus lesions in the rat. Brain Res 602:157-160, 1993

64. Quintana A, Melon C, Kerkerian-Le Goff L, Salin P, Savasta M, Sgambato-Faure V: Forelimb dyskinesia mediated by high-frequency stimulation of the subthalamic nucleus is linked to rapid activation of the NR2B subunit of N-methylD-aspartate receptors. Eur J Neurosci 32:423-434, 2010

65. Quintana A, Sgambato-Faure V, Savasta M: Effects of LDOPA and STN-HFS dyskinesiogenic treatments on NR2B regulation in basal ganglia in the rat model of Parkinson's disease. Neurobiol Dis 48:379-390, 2012

66. Rylander D, Iderberg H, Li Q, Dekundy A, Zhang J, Li H, et al: A mGluR5 antagonist under clinical development improves L-DOPA-induced dyskinesia in parkinsonian rats and monkeys. Neurobiol Dis 39:352-361, 2010

67. Rylander D, Recchia A, Mela F, Dekundy A, Danysz W, Cenci MA: Pharmacological modulation of glutamate transmission in a rat model of L-DOPA-induced dyskinesia: effects on motor behavior and striatal nuclear signaling. J Pharmacol Exp Ther 330:227-235, 2009

68. Sadikot AF, Parent A, François C: Efferent connections of the centromedian and parafascicular thalamic nuclei in the squirrel monkey: a PHA-L study of subcortical projections. J Comp Neurol 315:137-159, 1992 
69. Samadi P, Grégoire L, Morissette M, Calon F, Hadj Tahar A, Bélanger N, et al: Basal ganglia group II metabotropic glutamate receptors specific binding in non-human primate model of L-Dopa-induced dyskinesias. Neuropharmacology 54:258-268, 2008

70. Samadi P, Grégoire L, Morissette M, Calon F, Hadj Tahar A, Dridi M, et al: mGluR5 metabotropic glutamate receptors and dyskinesias in MPTP monkeys. Neurobiol Aging 29:1040-1051, 2008

71. Samadi P, Rajput A, Calon F, Grégoire L, Hornykiewicz O, Rajput AH, et al: Metabotropic glutamate receptor II in the brains of Parkinsonian patients. J Neuropathol Exp Neurol 68:374-382, 2009

72. Silverdale MA, Crossman AR, Brotchie JM: Striatal AMPA receptor binding is unaltered in the MPTP-lesioned macaque model of Parkinson's disease and dyskinesia. Exp Neurol 174:21-28, 2002

73. Silverdale MA, Kobylecki C, Hallett PJ, Li Q, Dunah AW, Ravenscroft P, et al: Synaptic recruitment of AMPA glutamate receptor subunits in levodopa-induced dyskinesia in the MPTP-lesioned nonhuman primate. Synapse 64:177-180, 2010

74. Smith Y, Charara A, Hanson JE, Paquet M, Levey AI: GABA(B) and group I metabotropic glutamate receptors in the striatopallidal complex in primates. J Anat 196:555-576, 2000

75. Smith Y, Charara A, Paquet M, Kieval JZ, Paré JF, Hanson $\mathrm{JE}$, et al: Ionotropic and metabotropic GABA and glutamate receptors in primate basal ganglia. J Chem Neuroanat 22:13-42, 2001

76. Smith Y, Hazrati LN, Parent A: Efferent projections of the subthalamic nucleus in the squirrel monkey as studied by the PHA-L anterograde tracing method. J Comp Neurol 294:306-323, 1990

77. Smith Y, Raju D, Nanda B, Pare JF, Galvan A, Wichmann T: The thalamostriatal systems: anatomical and functional organization in normal and parkinsonian states. Brain Res Bull 78:60-68, 2009

78. Smith Y, Wichmann T, Factor SA, DeLong MR: Parkinson's disease therapeutics: new developments and challenges since the introduction of levodopa. Neuropsychopharmacology 37:213-246, 2012

79. Steece-Collier K, Chambers LK, Jaw-Tsai SS, Menniti FS, Greenamyre JT: Antiparkinsonian actions of CP-101,606, an antagonist of NR2B subunit-containing N-methyl-d-aspartate receptors. Exp Neurol 163:239-243, 2000

80. Stocchi F, Rascol O, Destée A, Hattori N, Hauser RA, Lang AE, et al: AFQ056 in Parkinson patients with levodopa-induced dyskinesia: 13-week, randomized, dose-finding study. Mov Disord 28:1838-1846, 2013

81. Szabo J, Cowan WM: A stereotaxic atlas of the brain of the cynomolgus monkey (Macaca fascicularis). J Comp Neurol 222:265-300, 1984

82. Testa CM, Friberg IK, Weiss SW, Standaert DG: Immunohistochemical localization of metabotropic glutamate receptors mGluR1a and mGluR2/3 in the rat basal ganglia. J Comp Neurol 390:5-19, 1998

83. Walker RH, Koch RJ, Sweeney JE, Moore C, Meshul CK: Effects of subthalamic nucleus lesions and stimulation upon glutamate levels in the dopamine-depleted rat striatum. Neuroreport 20:770-775, 2009

84. Wolf E, Seppi K, Katzenschlager R, Hochschorner G, Ransmayr G, Schwingenschuh P, et al: Long-term antidyskinetic efficacy of amantadine in Parkinson's disease. Mov Disord 25:1357-1363, 2010

85. Zuddas A, Oberto G, Vaglini F, Fascetti F, Fornai F, Corsini GU: MK-801 prevents 1-methyl-4-phenyl-1,2,3,6-tetrahydropyridine-induced parkinsonism in primates. J Neurochem 59:733-739, 1992

\section{Author Contributions}

Conception and design: Di Paolo, Jourdain. Acquisition of data: Jourdain, Morin, Grégoire, Morissette. Analysis and interpretation of data: Di Paolo, Jourdain. Drafting the article: Jourdain. Critically revising the article: all authors. Reviewed submitted version of manuscript: all authors. Approved the final version of the manuscript on behalf of all authors: Di Paolo. Statistical analysis: Jourdain. Administrative/technical/material support: Grégoire, Morissette. Study supervision: Di Paolo.

\section{Correspondence}

Thérèse Di Paolo, Neuroscience Research Unit, Centre Hospitalier Universitaire de Québec, 2705 Laurier Boulevard, Quebec, QC G1V 4G2, Canada. email: therese.dipaolo@crchul.ulaval.ca. 